\title{
Hilfsbüchlein
}

für den

\section{römischen Zivilprozess}

zum Gebrauch bei Vorlesung und Studium.

\author{
Auf der Grundlage der Vorlesungsbeilagen \\ von $\mathrm{O}$. Fischer und $\mathrm{R}$. Schott \\ herausgegeben von
E. F. Bruck, O. Fischer, F. Klingmüller, R. Leonhard und R. Schott
in Breslau.

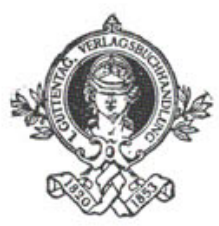

Berlin 1911.

J. Guttentag, Verlagsbuchhandlung,

G. m. b $\mathrm{H}$. 
